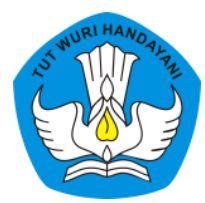

Page: 93-116

\title{
Penggunaan Model Jiqsaw Berbantuan Media Geoboard untuk Meningkatkan Hasil Belajar Matematika
}

\author{
Timbul Amar Hotib \\ Sekolah Dasar Negeri 114340 Pekan Tolan Labuhanbatu Selatan \\ Contributor Email: amarhotib78@gmail.com
}

Published: Mar 30, 2020

Article Url: http:/ / ojsdikdas.kemdikbud.go.id/index.php/didaktika/article/view/133

\begin{abstract}
The purpose of this research use the Jiqsaw learning model assisted by Geoboard media is to find out the steps to use the Jiqsaw learning model assisted by Geoboard Media and to improve Mathematics learning outcomes of 114340 Public Elementary School students in Tolan Week. The design of this study uses Classroom Action Research (CAR) which consists of two cycles with each cycle consisting of 3 face-toface meetings. Learning outcomes are measured based on a written test. Increased student learning outcomes in the Coordinate Field, then the average value of students is 52.72 with 11 students who have mastery (50.50\%) and 11 students who have not completed $(50.50 \%)$ of all students. Then the action was taken using Mathematics, then obtained an average value increased to 61.82 with 16 students who experienced mastery $(72.73 \%)$ and 6 students who had not completed $(27.27 \%)$. After learning innovation using Mathematics assisted by the jiqsaw model, the average grade value was increased to 76.36 with 19 students experiencing mastery (86.36\%) and 3 students who did not complete $(13.64 \%)$.
\end{abstract}

Keywords: Jiqsaw Model, Geoboard, and Learning Outcomes 


\begin{abstract}
Abstrak
Tujuan penelitian ini adalah menggunakan model pembelajaran Jiqsaw berbantuan media Geoboard adalah untuk mengetahui langkah-langkah penggunaan model pembelajaran Jiqsaw berbantuan Media Geoboard dan untuk meningkatkan hasil belajar Matematika siswa SD Negeri 114340 Pekan Tolan. Desain penelitian ini menggunakan Penelitian Tindakan Kelas (PTK) yang terdiri dari dua siklus dengan setiap siklusnya terdiri dari 3 tatap muka (pertemuan). Hasil belajar diukur berdasarkan tes tertulis.. Peningkatan hasil belajar siswa pada Bidang Koordinat, maka diperoleh nilai rata-rata siswa sebesar 52,72 dengan 11 siswa yang mengalami ketuntasan (50,50\%) dan 11 siswa yang belum tuntas (50,50\%) dari keseluruhan siswa. Kemudian dilakukan tindakan menggunakan Matematika, maka diperoleh nilai rata-rata meningkat menjadi 61,82 dengan 16 siswa yang mengalami ketuntasan $(72,73 \%)$ dan 6 siswa yang belum tuntas (27,27\%). Setelah dilakukan inovasi pembelajaran menggunakan Matematika berbantuan model jiqsaw, maka diperoleh nilai rata-rata kelas meningkat menjadi 76,36 dengan 19 siswa yang mengalami ketuntasan (86,36\%) dan 3 siswa yang belum tuntas (13,64\%).
\end{abstract}

Kata Kunci: Model Jiqsaw, Geoboard, dan Hasil Belajar

\title{
A. Pendahuluan
}

Siswa kelas VI Sekolah Dasar (SD) seharusnya mampu menentukan posisi titik dalam sistem koordinat Kartesius dengan jawaban yang benar, bahkan harus mampu menentukan ordinat dan absis suatu benda pada kertas kartesius. Yang pada tahap selanjutnya mampu menentukan hasil bayangan atau hasil pencerminan dari suatu benda dalam pemecahan masalah. Dalam Peraturan Menteri Pendidikan Nasional Nomor 22 Tahun 2006 Tentang Standar isi (2008:167) disebutkan bahwa, "Siswa kelas IV SD harus memiliki kompetensi menggunakan sistem koordinat dalam pemecahan masalah.

Berdasarkan hasil supervisi Kepala Sekolah dan wawancara dengan peneliti kebetulan guru kelas VI bahwa siswa kelas VI sangat sulit memahami materi Bidang Koordinat tersebut, hal ini terlihat : Siswa sulit menentukan koordinat posisi yang tepat pada sebuah benda, sulit menjelaskan posisi titik dalam sistim koordinat kertas kartesius, dan sulit menjawab dengan benar apabila soal bidang koordinat dalam pemecahan masalah. 
Di samping itu aktivitas siswa kurang aktif. Hal ini terlihat ketika peneliti menjelaskan materi kordinat sebanyak 10 siswa ribut, sebanyak 2 siswa jalan-jalan di kelas, 10 siswa yang aktif, bahkan ketika guru mengajukan pertanyaan, maka satu siswapun tidak ada yang bertanya. Tidak adil jika penyebab rendah nilai siswa disebabkan dari masalah siswa itu sendiri, akan tetapi dari aspek peneliti juga belum menggunakan media pembelajaran yang inovatif dalam pembelajaran, cenderung memakai kertas kartesius dan buku paket.

Peneliti menggunakan model pembelajaran Jiqsaw berbantuan media Geoboard untuk menarik perhatian siswa, dan untuk mengaktifkan siswa dalam mencapai tujuan pembelajaran menggunakan sistim koordinat dalam pemecahan masalah bidang koordinat. Menurut pendapat Isjoni, (2009:14) bahwa, "Pembelajaran kooperatif adalah salah satu bentuk pembelajaran yang berdasarkan faham konstruktivis. Pembelajaran kooperatif merupakan strategi belajar dengan sejumlah siswa sebagai anggota kelompok kecil yang tingkat kemampuannya berbeda. Dalam menyelesaikan tugas kelompoknya, setiap siswa anggota kelompok harus saling bekerja sama dan saling membantu untuk memahami materi pelajaran. Dalam pembelajaran kooperatif, belajar dikatakan belum selesai jika salah satu teman kelompok belum menguasai bahan pelajaran".

Adapun menurut Suprijono Agus, (2010:54) menyatakan bahwa, “Pembelajaran kooperatif adalah konsep yang lebih luas meliputi semua jenis kerja kelompok termasuk bentuk-bentuk yang lebih dipimpin oleh guru atau diarahkan oleh guru". Berdasarkan kedua pendapat di atas, maka peneliti menyimpulkan bahwa pembelajaran kooperatif itu merupakan salah satu pendekatan belajar dengan ciri khasnya harus ada dibentuk kelompok untuk mempelajari materi yang berbeda-beda antara satu kelompok dengan kelompok lain.

Pembelajaran cooperative tyipe Jigsaw adalah pembelajaran dengan model jiqsaw diawali dengan pengenalan topik yang akan dibahas guru. Guru biasanya menuliskan topik yang akan dipelajari pada 
papan tulis, white board, penayangan power point dan sebagainya, (Istarani, 2012:25). Langkah-langkah dalam penerapan teknik Jigsaw adalah sebagai berikut : (1) Siswa dikelompokkan ke dalam +4 anggota tim, (2) Tiap orang dalam tim diberi bagian materi yang berbeda, (3) Tiap orang dalam tim diberi bagian materi yang ditugaskan, (4) Anggota tim yang berbeda yang telah mempelajari bagian/sub bab yang sama bertemu dalam kelompok baru (kelompok ahli) untuk mendiskusikan sub bab mereka, (5) Setelah selesai diskusi sebagai tim ahli setiap anggota kembali ke kelompok asal dan bergantian menjelaskan kepada teman satu tim mereka tentang sub bab yang mereka kuasai dan tiap anggota lainnya mendengarkan dengan sungguh-sungguh, (6) Tiap tim ahli mempresentasikan hasil diskusi, (7) Guru memberikan evaluasi, dan (8) Penutup. (Istarani, 2012:25).

Arsyad Azhari (2011:4) menyatakan, "Media adalah komponen sumber belajar atau wahana fisik yang mengandung materi instruksional di lingkungan siswa yang dapat merangsang siswa untuk belajar". Sedangkan pendapat Sukiman (2012:29), “ Media adalah segala sesuatu yang dapat digunakan untuk menyalurkan pesan dari pengirim ke penerima sehingga merangsang pikiran, perasaan, perhatian dan minat serta kemauan siswa".

Geoboard merupakan istilah lain dari papan berpaku. Geoboard ini peneliti modifikasi dari penelitian sebelumnya. Geoboard (papan berpaku) termasuk alat peragaan display yang terdiri dari bagian media visual. Menurut (Munadi:2013: 81), media visual adalah media yang melibatkan indera penglihatan.

Berdasarkan pendapat di atas, yang dimaksud dengan media Geoboard adalah segala sesuatu alat bantu yang dapat dilihat karena bagian dari media visual dan menjadi penghubung antara guru dan siswa, dimana penghubung tersebut memudahkan siswa untuk memahami pelajaran, bahkan merupakan alat permainan sehingga 
menarik perhatian siswa dalam belajar. Dengan demikian media Geoboard merupakan alat bantu media visual dalam bentuk peragaan untuk menyampaikan konsep materi pelajaran sehingga dapat memudahkan siswa memahami konsep tersebut. Selanjutnya dapat meningkatkan hasil belajar siswa pada mata pelajaran Matematika Kelas 4 dengan Materi Bidang Koordinat. Media Geoboard Matematika merupakan alat yang terbuat dari kayu, triplek, karton yang dirakit menjadi papan berpaku yang dapat dimainkan anak-anak menggunakan karet untuk membentuk persegi,persegi panjang, segitiga, trapesiaum, belah ketupat dan layang-layang.

Apabila dalam proses belajar tidak menggunakan media pembelajaran, maka siswa akan sulit memahami materi bidang koordinat pada pertemuan berikutnya, oleh karena itu peneliti ingin memecahkan masalah ini dengan mengadakan penelitian inovasi pembelajaran yang berjudul, "Penggunaan Model Jiqsaw Berbantuan Media Geoboard Untuk Meningkatkan Hasil Belajar “.

Merujuk pada pendahuluan di atas, maka dapat dirumuskan masalah pada inovasi pembelajaran ini adalah: Bagaimanakah langkahlangkah penggunaan media Geoboard berbantuan model pembelajaran tipe Jiqsaw? Penggunaan Model Jiqsaw berbantuan Media Geoboard berbantuan model bertujuan untuk mengetahui langkah-langkah penggunaan media Geoboard berbantuan model pembelajaran jiqsaw dan bagaimanakah peningkatan hasil belajar setelah menggunakan media geoboard berbantuan model pembelajaran jiqsaw?

Implementasi inovasi pembelajaran ini memiliki banyak manfaat, yaitu (1) Meningkatkan pengetahuan tentang langkah-langkah model Jiqsaw berbantuan Geoboard, (2) untuk meningkatkan hasil pembelajaran Matematika dengan memanfaatkan benda-benda yang banyak tersedia di lingkungan anak-anak, (3) sebagai referensi di perpustakaan sekolah. 


\section{B. Metode}

Desain penelitian ini menggunakan metode penelitian tindakan kelas, yang bertujuan untuk melihat peningkatan dari perlakukan tahap pertama dan tahap kedua. Apakah peningkatan tersebut berpengarruh dan signifikansi (lihat alur penelitian tindakan kelas, Gambar 1).

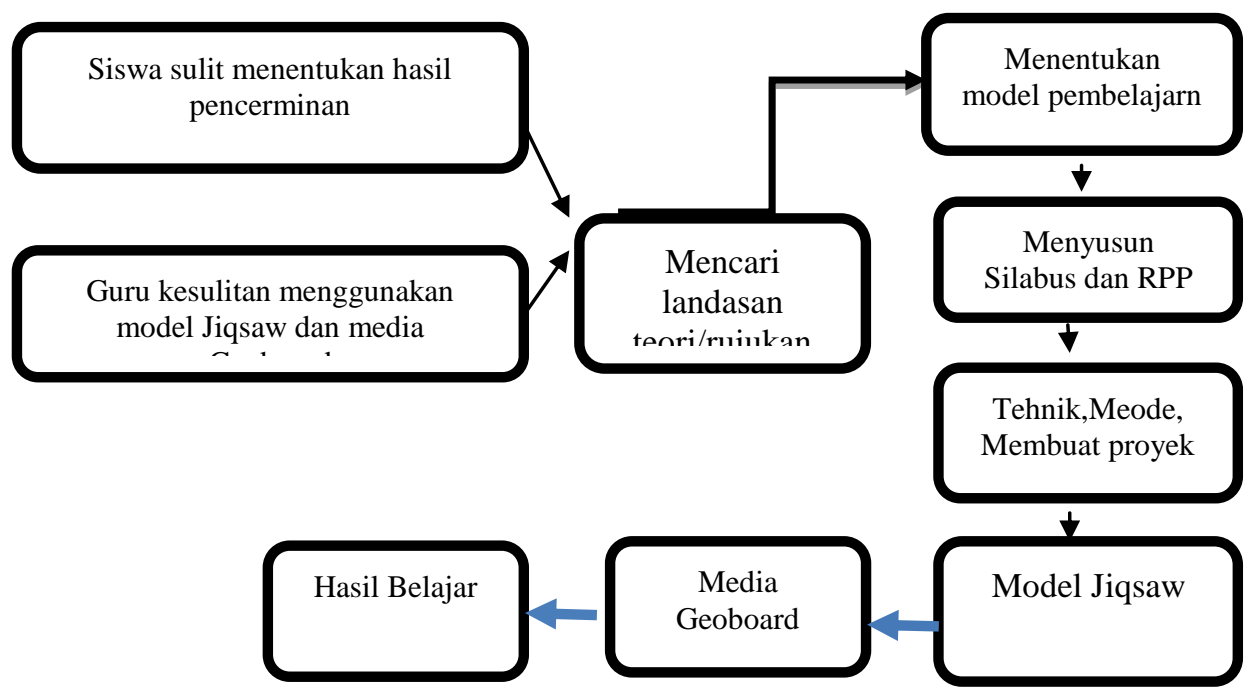

Gambar 1. Alur Penelitian Tindakan kelas

Subjek penelitian adalah siswa kelas VI Semester Genap Tahun Pelajaran 2017/2018 SD Negeri 114340 Pekan Tolan yang berjumlah 22 siswa, 13 laki-laki dan 9 perempuan. Penelitian ini dilakukan selama 3 bulan, mulai dari Senin, 06 Pebruari 2017, Rabu, 8 Pebruari 2017, Jum'at, 10 Pebruari 2017, Senin, 13 Pebruari 2017, Rabu, 15 Pebruari 2017, dan Jum'at, 17 Pebruari 2017.

Instrumen yang digunakan adalah tes tertulis bentuk uraian, angket dan pedoman obeservasi. Ketiga instrumen ini dilakukan dengan distribusi instrumen tes tertulis uraian dan angket serta dilakukan pengamatan terhadap seluruh kegiatan pengajaran yang dilakukan dari awal tindakan sampai berakhirnya pelaksanaan tindakan. Obeservasi dimaksudkan untk mengetahui keseesuaian tindakan dengan rencana yang telah disusun dan 
untuk mengetahui sejauhmana pelaksanaan tindakan dapat menghasilkan perubahan yang sesuai dengan yang dikehendaki.

\section{Hasil dan Pembahasan}

\section{Hasil}

Hasil penelitian ini terdiri dari hasil pra siklus, siklus 1, dan siklus 2. Untuk lebih jelasnya peneliti memaparkan hasil penelitian pada pra siklus sebelum menggunakan model pembelajaran jiqsaw dan media geoboard. Perbandingan Tuntas dan Tidak Tuntas pada pra siklus adalah siswa yang tuntas adalah sebanyak 2 siswa dan yang belum tuntas sebesar 20 siswa. dengan ini dapat diketahui persentase ketuntasan klasikal yaitu PKK $=2 / 22 \times 100 \%=9,09 \%$ dan persentase yang belum tuntas yaitu $20 / 22 \times 100 \%=90,09 \%$. Hasil penelitian ini menunjukkan tingkat ketuntasan belajar secara klasikal masih rendah, maka selanjutnya dilakukan perbaikan dengan penerapan model pembelajaran kooperatif Jiqsaw berbantuan media geoboard untuk melihat apakah peningkatan hasil belajar siswa materi Bidang Kordinat betul-betul terjadi.

Melalui hasil peningkatan ketuntasan belajar sangat rendah, maka peneliti melakukan Siklus I pada minggu I dan Minggu II yaitu 3 kali pertemuan tatap muka dengan rincian sebagai berikut: Pertemuan pertama pada siklus I Minggu I, hari Senin, 06 Pebruari 2017 Sesuai skenario yang telah dirancang dalam pelaksanaan penelitian ini menemukan ada 3 siswa mampu membaca denah sederhana pada papan berpaku, sedangkan 10 siswa yang tidak mampu membaca denah sederhana yang mana mereka hanya menebak, sehingga hasilnya belum tepat, dan 9 siswa kebingungan. Dalam melengkapi titik-titik sudah 25\% mampu menjawab dengan benar, sekitar 5 siswa yang benar-benar mampu melengkapi titik-titik, sedangkan $75 \%$ sekitar 17 siswa belum dapat melengkapi titik-titik dengan benar. Setelah peneliti amati hal itu disebabkan karena ketidak fahaman siswa tentang arah mata angin, sehingga jawaban seharusnya Barat di jawabnya Timur. 
Pertemuan kedua pada siklus I Minggu I hari Rabu, 8 Pebruari 2017. Hal yang ditemukan oleh peneliti pada pertemuan ini hampir sama dengan pertemuan pertama, bedanya hanya siswa yang diminta menunjukkan letak benda pada papan berpaku. iketahui bahwa ada 5 siswa yang mampu, sehingga ada 2 siswa mengalami perubahan. Pada pertemuan kedua ini hampir semua siswa sudah mampu menentukan arah mata angin, hanya saja kadang-kadang sebahagian ikut-ikutan jawaban kawannya. Pembelajaran bidang kordinat ini masih baru untuk siswa. Capaian indikator menunjukkan letak benda, menulis letak benda di buku tulis masih seperti pertemuan pertama. Permasalahan yang ditemukan siswa belum mampu menunjukkan benda jika diacak tempat benda tersebut. Hal ini disebabkan karena siswa kurang faham materi yang dipelajari, namun tidak berani bertanya.

Pertemuan ketiga pada siklus I Minggu I hari Jum'at, 10 Pebruari 2017 Pada pertemuan ini, sudah ada 6 siswa yang mampu menggambar letak benda menggunakan karet gelang di papan berpaku walaupun masih lambat sehingga waktunya habis dan menggambar belum selesai. Sekitar 27\% siswa sudah mampu menggambarkan letak benda, dan 73\% lagi harus lebih sering membaca dan menunjukkan letak benda sehingga pada gilirannya pandai menggambar letak benda di buku tulis petak masing-masing. Permasalahan yang ditemukan siswa banyak yang tidak aktif bahkan ada 3 orang yang jalan-jalan di ruangan kelas.

Pertemuan keempat pada siklus I Minggu II hari Senin, 13 Pebruari 2017 pada pertemuan keempat ini indikatornya menentukan letak kordinat posisi benda pada papan berpaku. Hasil yang ditemukan adalah 7 siswa mampu menentukan letak kordinat yang benar, sedangkan 15 siswa belum mampu. Permasalahan yang ditemukan yaitu 15 siswa menentukan letak kordinat benda itu terbalik seperti rumah Ari seharusnya $(\mathrm{A}, 2)$ dijawabnya $(2, \mathrm{~A})$. Ketika ditanya pada kordinat C,4 menunjukkan letak apa? Maka jawabannya banyak yang salah.

Pertemuan kelima pada siklus I Minggu II hari Rabu, 15 Pebruari 2017 pada pertemuan ini indikatornya menentukan letak kordinat posisi 
tempat pada papan berpaku. Hasil yang ditemukan mengalami peningkatan yaitu sebanyak 8 siswa sudah mampu menentukan letak kordinat posisi tempat, sedangkan 14 siswa belum mampu. Ketika peneliti bertanya kepada siswa, "kenapa kalian kesulitan menentukan letak kordinat posisi tempat?" maka siswa menjawab, "kami tidak faham pak, karena kami kurang konsentrasi".

Pertemuan keenam pada siklus I Minggu II Jum'at, 17 Pebruari 2017 indikator yang harus dicapai siswa yaitu menggambarkan letak kordinat posisi benda pada papan berpaku. Hasil yang ditemukan sebanyak 10 siswa sudah mampu menggambarkan letak kordinat posisi benda pada papan berpaku dan pada buku petak, sedangkan 8 siswa gambarnya ada yang benar dan ada yang salah, serta 4 siswa semua gambarnya salah. Permasalahan yang ditemukan yaitu siswa takut disuruh maju ke depan untuk mempraktikkan menggambarkan letak kordinat benda pada papan berpaku.

Observasi dilakukan sepanjang pelaksanaan tindakan siklus 1 dengan menggunakan alat bantu daftar centang (checklist). Hasil observasi antara lain masih sedikit siswa yang mampu membaca denah pada papan berpaku, yakni sebanyak 3 siswa, sebanyak 5 siswa sudah mampu menunjukkan letak benda, sebanyak 6 siswa sudah mampu mendemonstrasikan cara penggunaan papan berpaku menggunakan karet gelang untuk melengkapi titik, sebanyak 7 siswa mampe menentukan letak benda, sebanyak 8 siswa mampu menentukan letak tempat/kota dan sebanyak 10 siswa mampu menggambarkan letak koordinat posisi benda.

KKM sehingga peneliti merasakan ada kegagalan dalam menerapkan tindakan siklus satu ini.

Pada kegiatan ini peneliti mengevaluasi semua tahap kegiatan yang dilakukan mulai dari pelaksanaan tindakan hingga observasi hasilnya sebagai mana terdapat pada tabel-tabel berikut: 
Tabel 1. Hasil Nilai Siklus I Pertemuan ke-1-3

\begin{tabular}{|c|c|c|c|c|}
\hline \multirow{3}{*}{ No } & \multirow{3}{*}{$\begin{array}{l}\text { Kode Nama } \\
\text { Siswa }\end{array}$} & \multicolumn{3}{|c|}{ Siklus 1} \\
\hline & & \multicolumn{3}{|c|}{ Pertemuan Ke } \\
\hline & & 1 & 2 & 3 \\
\hline 1 & $\mathrm{Ah}$ & 60 & 83 & 80 \\
\hline 2 & $\mathrm{Ah}$ & 30 & 50 & 40 \\
\hline 3 & $\mathrm{Bn}$ & 50 & 33 & 80 \\
\hline 4 & $\mathrm{Cp}$ & 40 & 50 & 40 \\
\hline 5 & Fr & 20 & 50 & 40 \\
\hline 6 & $\mathrm{Fa}$ & 100 & 50 & 60 \\
\hline 7 & $\mathrm{Ga}$ & 60 & 67 & 40 \\
\hline 8 & $\mathrm{He}$ & 60 & 100 & 100 \\
\hline 9 & Ih & 20 & 33 & 40 \\
\hline 10 & $\mathrm{Jp}$ & 40 & 33 & 40 \\
\hline 11 & Jh & 0 & 33 & 40 \\
\hline 12 & Lh & 40 & 67 & 40 \\
\hline 13 & Ms & 20 & 50 & 80 \\
\hline 14 & Ms & 50 & 50 & 60 \\
\hline 15 & $\mathrm{Nw}$ & 20 & 50 & 40 \\
\hline 16 & $\mathrm{Rh}$ & 20 & 50 & 40 \\
\hline 17 & Rs & 60 & 83 & 80 \\
\hline 18 & TK & 20 & 50 & 40 \\
\hline 19 & TF & 20 & 67 & 60 \\
\hline 20 & TI & 20 & 33 & 40 \\
\hline 21 & Ws & 20 & 33 & 60 \\
\hline 22 & Ys & 70 & 83 & 60 \\
\hline \multicolumn{2}{|c|}{ Jumlah } & 840 & 1198 & 1200 \\
\hline \multicolumn{2}{|c|}{ Rata-rata } & 38,18 & 54,45 & 54,45 \\
\hline \multicolumn{2}{|c|}{$\begin{array}{l}\text { Jumlah Siswa Yang } \\
\text { Tuntas }\end{array}$} & $5=22,73 \%$ & $7=31,82 \%$ & $10=45,45 \%$ \\
\hline \multicolumn{2}{|c|}{$\begin{array}{l}\text { Jumlah Siswa Yang } \\
\text { Belum Tuntas }\end{array}$} & $17=77,27 \%$ & $15=68,18 \%$ & $12=54,55 \%$ \\
\hline
\end{tabular}

Peneliti meminta bantuan kepada ibu Asma Rambe, S.Pd sebagai (teman sejawat) untuk mengamati peneliti selama melangsungkan Proses Belajar Mengajar (PBM) dengan menerapkan Model Jiqsaw Berbantuan Geoboard. Berikut disajikan hasil pengamatan pada siklus I Pertemuan ke-1 sd pertemuan 3. 
Tabel 2. Hasil Observasi Aktivitas Guru Pada Saat Siklus I Pertemuan 1 sd 3

\begin{tabular}{|c|c|c|c|c|c|c|c|c|c|}
\hline \multirow{4}{*}{ Aspek } & \multirow{4}{*}{ Indikator } & \multicolumn{8}{|c|}{ Diskriptor Siklus I } \\
\hline & & \multicolumn{8}{|c|}{ Minggu I } \\
\hline & & \multicolumn{3}{|c|}{$\begin{array}{c}\text { Pertem } \\
\text { uan } 1\end{array}$} & \multicolumn{3}{|c|}{$\begin{array}{c}\text { Pertem } \\
\text { uan } 2 \\
\end{array}$} & \multicolumn{2}{|c|}{$\begin{array}{c}\text { Pertem } \\
\text { uan } 3\end{array}$} \\
\hline & & $\mathbf{1}$ & \begin{tabular}{l|l|}
2 & 3 \\
\end{tabular} & 4 & $\mathbf{1}$ & 23 & 4 & \begin{tabular}{l|l}
1 & 2 \\
\end{tabular} & 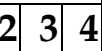 \\
\hline \multirow{3}{*}{$\begin{array}{l}\text { A. } \\
\text { Membu } \\
\text { ka } \\
\text { pelajara } \\
\text { n }\end{array}$} & 1. Menarik perhatian siswa & & $\sqrt{ }$ & & & $\sqrt{ }$ & & & $\sqrt{ }$ \\
\hline & $\begin{array}{l}\text { 2. Menjelaskan tujuan } \\
\text { pembelajaran }\end{array}$ & & $\sqrt{ }$ & & & $\sqrt{ }$ & & & $\sqrt{ }$ \\
\hline & $\begin{array}{l}\text { 3. Membagi dan menyusun } \\
\text { kelompok }\end{array}$ & & $\sqrt{ }$ & & & $\sqrt{ }$ & & & $\sqrt{ }$ \\
\hline \multirow{3}{*}{$\begin{array}{l}\text { B. } \\
\text { Penggu } \\
\text { naan } \\
\text { waktu } \\
\text { dan } \\
\text { strategi } \\
\text { pembel } \\
\text { ajaran }\end{array}$} & $\begin{array}{l}\text { 1. Menyediakan sumber } \\
\text { belajar dan } \\
\text { alat-alat bantu } \\
\text { pembelajaran }\end{array}$ & & $\sqrt{ }$ & & & $\sqrt{ }$ & & & $\sqrt{ }$ \\
\hline & $\begin{array}{l}\text { 2. Melaksanakan kegiatan } \\
\text { pembelajaran sesuai } \\
\text { dengan tujuan } \\
\text { pembelajaran terurut }\end{array}$ & & $\sqrt{ }$ & & & $\sqrt{ }$ & & & $\sqrt{ }$ \\
\hline & $\begin{array}{l}\text { 3. Mendemonstrasikan } \\
\text { cara menentukan letak } \\
\text { titik kordinat datar di } \\
\text { depan kelas }\end{array}$ & $\sqrt{ }$ & & & & $\sqrt{ }$ & & & $\sqrt{ }$ \\
\hline \multirow{2}{*}{$\begin{array}{l}\text { C. } \\
\text { Melibat } \\
\text { kan } \\
\text { proses } \\
\text { pembel } \\
\text { ajaran }\end{array}$} & $\begin{array}{l}\text { 1. Upaya guru melibatkan } \\
\text { siswa dalam proses } \\
\text { pembelajaran }\end{array}$ & & $\sqrt{ }$ & & & $\sqrt{ }$ & & & $\sqrt{ }$ \\
\hline & $\begin{array}{l}\text { 2. Mengamati kegiatan } \\
\text { siswa dalam } \\
\text { berkelompok }\end{array}$ & & $\sqrt{ }$ & & & $\sqrt{ }$ & & & $\sqrt{1}$ \\
\hline \multirow{2}{*}{$\begin{array}{l}\text { D. } \\
\text { Komun } \\
\text { ikasi } \\
\text { dengan } \\
\text { siswa }\end{array}$} & $\begin{array}{l}\text { 1. Upaya guru melibatkan } \\
\text { siswa dalam proses } \\
\text { pembelajaran }\end{array}$ & & $\sqrt{ }$ & & & $\sqrt{ }$ & & & $\sqrt{ }$ \\
\hline & $\begin{array}{l}\text { 2. Mengamati kegiatan } \\
\text { siswa dalam } \\
\text { menggunakan alat } \\
\text { peraga dan dalam } \\
\text { menyelesaikan tugas }\end{array}$ & $\sqrt{ }$ & & & & $\sqrt{ }$ & & & $\sqrt{ }$ \\
\hline
\end{tabular}




\begin{tabular}{|c|c|c|c|c|c|c|c|c|c|}
\hline & yang diberikan & & & & & & & & \\
\hline & $\begin{array}{l}\text { 3. Mengembangkan } \\
\text { keberanian siswa } \\
\text { dalam } \\
\text { mengemukakan } \\
\text { pendapat. }\end{array}$ & & & & $\sqrt{ }$ & & & $\sqrt{ }$ & \\
\hline $\begin{array}{l}\text { E. } \\
\text { Menut } \\
\text { up } \\
\text { Pelajar } \\
\text { an }\end{array}$ & 1. Merangkum isi pelajaran & & 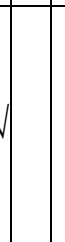 & & $\sqrt{ }$ & & & $\sqrt{ }$ & \\
\hline & Jumlah & & - & - & $\begin{array}{r}1 \\
-\quad 2 \\
\end{array}$ & - & - & \begin{tabular}{|l|}
1 \\
0
\end{tabular} \mid & 2 \\
\hline & Total & & $\begin{array}{l}=45, \\
3 \%\end{array}$ & & $\begin{array}{r}24= \\
00\end{array}$ & $\begin{array}{l}=50, \\
\%\end{array}$ & & $\begin{array}{r}26= \\
170\end{array}$ & $\begin{array}{l}54, \\
\%\end{array}$ \\
\hline
\end{tabular}

\section{Kriteria}

86-100 = Sangat Baik

71-85 = Baik

60-70 = Cukup

0-59 =Kurang

Peneliti meminta bantuan kepada ibu Asma Rambe, S.Pd sebagai (teman sejawat) untuk mengamati siswa selama melangsungkan Proses Belajar Mengajar (PBM) dengan menerapkan Papan berpaku. Berikut disajikan hasil pengamatan pada siklus I Pertemuan ke-1 sd pertemuan 3

Tabel 3. Hasil Observasi Aktivitas Siswa pada Saat Kegiatan Belajar

Minggi I dan II Siklus I Pertemuan ke-1 sd 3

\begin{tabular}{|c|c|c|c|c|c|c|}
\hline \multirow{4}{*}{ Aspek } & \multirow{4}{*}{ Indikator } & \multirow{2}{*}{\multicolumn{5}{|c|}{ Diskriptor Siklus I }} \\
\hline & & \multicolumn{4}{|c|}{ Minggu II } & \\
\hline & & $\begin{array}{l}\text { Pertem } \\
\text { uan } 4\end{array}$ & \multicolumn{2}{|c|}{$\begin{array}{l}\text { Pertem } \\
\text { uan } 5\end{array}$} & \multicolumn{2}{|c|}{$\begin{array}{c}\text { Pertem } \\
\text { uan } 6\end{array}$} \\
\hline & & \begin{tabular}{l|l|l|l}
1 & 2 & 3 & 4
\end{tabular} & \begin{tabular}{|l|l|}
1 & 2 \\
\end{tabular} & 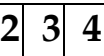 & \begin{tabular}{|l|l|l|}
1 & 2 \\
\end{tabular} & 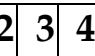 \\
\hline $\begin{array}{ll}\text { A. } & \text { Te } \\
\text { kun } & \end{array}$ & $\begin{array}{l}\text { a. Melakukan kegiatan } \\
\text { belajar terus menerus }\end{array}$ & V & & $\sqrt{ }$ & & $\sqrt{1}$ \\
\hline
\end{tabular}

104\} Direktorat GTK Pendidikan Dasar Kemdikbud RI 


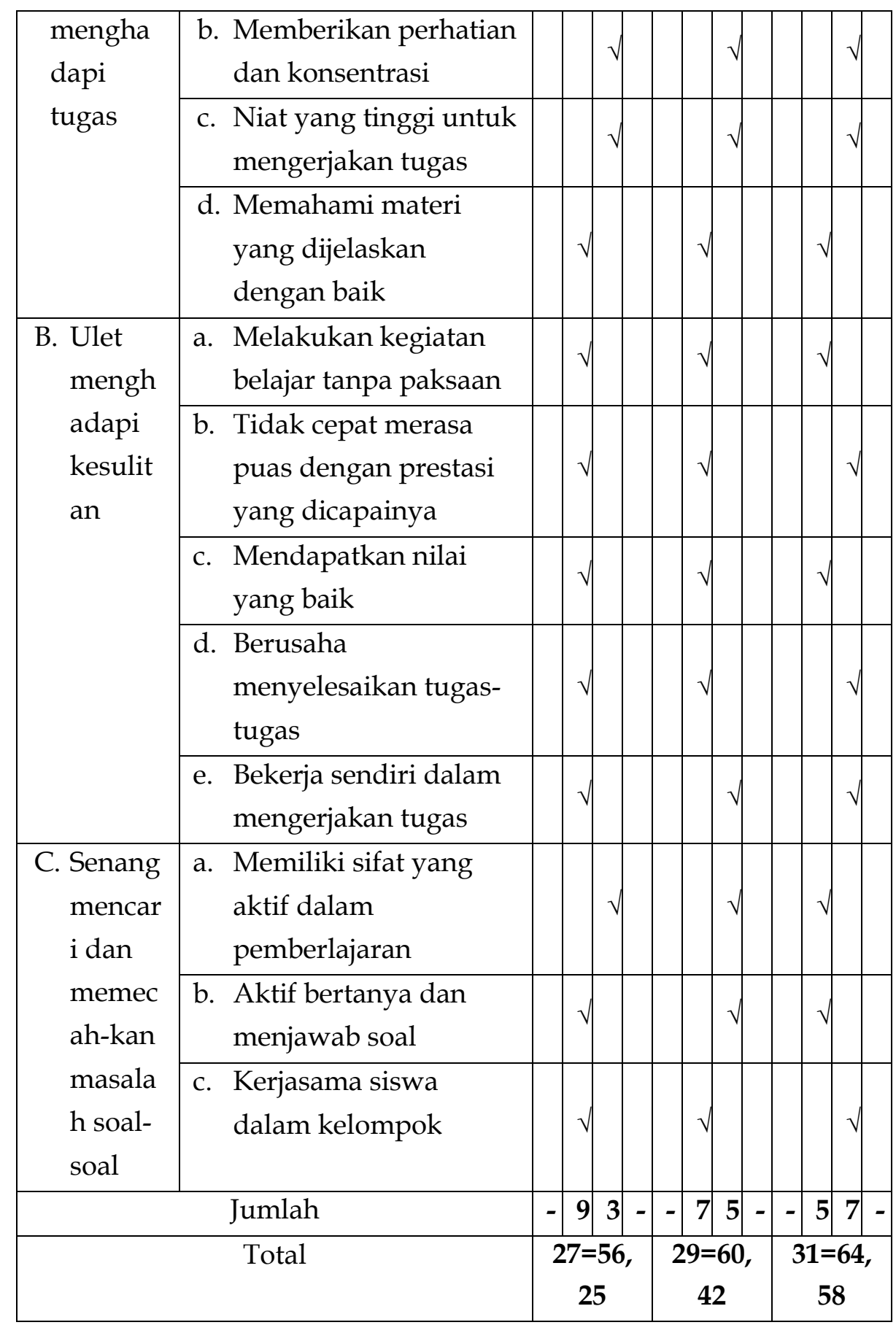




\section{Kriteria}

86-100= Sangat Baik

71-85 = Baik

60-70 = Cukup

0-59 =Kurang

Berdasarkan hasil pelaksanaan dan observasi yang dilakukan pada siklus 1 pertemuan 1-3, maka peneliti melakukan refleksi terhadap keseluruhan kegiatan pada siklus I yang hasilnya sebagai berikut: Bahwa jumlah siswa yang mencapai KKM 60 adalah 10 siswa atau sebesar $27,27 \%$, aktivitas guru sebesar $64,58 \%$, dan aktivitas siswa sebesar $66,67 \%$. Berhubung nilai siswa belum mencapai KKM sebesar $60 \%$, aktivitas guru masih kategori cukup, dan aktivitas siswa juga masih kategori cukup, maka penelitian ini lanjut ke siklus II.

Berdasarkan hasil observasi peneliti merefleksikan tindakan siklus II sebagai berikut: Pada siklus II seluruh indikator yang dilakukan sudah mengalami peningkatan, yaitu siswa sudah terampil menggambar benda sudah mencapai 18 siswa yang mampu menentukan hasil pencerminan jika dipantulkan sumbu $X$ atau $Y$ di papan berpaku sudah 18 siswa yang benar.

Setelah refleksi tindakan siklus II juga peneliti mengevaluasi semua tahap kegiatan mulai dari tindakan sampai observasi aktivitas siswa dan hasil observasi aktivitas guru yang telah dicapai pada siklus II dapat dilihat pada tabel 4 di bawah ini:

Dari data siklus II observasi aktivitas siswa di atas, dapat dideskripsikan hal-hal sebagai berikut: (1) Pertemuan pertama indikator kategori sangat baik sebanyak 1 yaitu indikator niat yang tinggi untuk mengerjakan tugas, kategori baik sebanyak 9, dan kategori cukup sebanyak, (2) Pertemuan kedua indikator kategori baik sebanyak 12, (3) Pertemuan kedua indikator kategori sangat baik sebanyak 2, kategori baik sebanyak 10 .

Skor rata-rata nilai siswa pada akhir siklus II adalah 75,45 atau sebanyak 18 siswa sudah mencapai nilai di atas KKM, hasil pengamatan 
aktivitas siswa pada saat pembelajaran sudah 93,75\% dan aktivitas guru pada saat pembelajaran sudah $91,67 \%$. Dari data tersebut jelas terlihat bahwa dengan menggunakan papan berpaku secara optimal pada materi bidang kordinat kelas VI mata pelajaran Matematika mengalami peningkatan dengan baik. Tingkat ketercapaian keberhasilan siswa yang tuntas KKM sudah $81,81 \%$, sehingga dapat dikatakan bahwa tindakan sikulus II ini sudah berhasil secara klasikal.

Hasil dapat disajikan dalam bentuk tabel angka-angka, grafik, deskripsi verbal, atau gabungan antara ketiganya. Tabel, grafik, atau gambar tidak boleh terlalu panjang, terlalu besar, atau terlalu banyak. Penulis sebaiknya menggunakan variasi penyajian tabel, grafik, atau deskripsi verbal. Tabel dan grafik yang disajikan harus dirujuk dalam teks. Cara penulisan tabel ditunjukkan pada Tabel 1. Tabel tidak memuat garis vertikal (tegak) dan garis horizontal (datar) hanya ada di kepala dan ekor tabel. Ukuran huruf isian tabel dan gambar boleh diperkecil. Angkaangka di dalam tabel tidak boleh diulang-ulang dalam narasi verbal baik sebelum maupun sesudahnya.

\begin{tabular}{|c|c|c|c|}
\hline No. & Nama Bagian & $\begin{array}{l}\text { Panjang dalam } \\
\text { Persen (\%) }\end{array}$ & Keterangan \\
\hline 1. & Pendahuluan & 20 & $\begin{array}{l}\text { Maksimum (termasuk } \\
\text { judul dan abstrak) }\end{array}$ \\
\hline 2. & Metode & 10 & $\begin{array}{l}\text { Untuk penelitian } \\
\text { kuantitatif dapat sampai } \\
15 \% \text {. }\end{array}$ \\
\hline 3. & Hasil dan Pembahasan & 60 & Minimal \\
\hline 5. & $\begin{array}{l}\text { Penutup dan Daftar } \\
\text { Pustaka }\end{array}$ & 10 & Kurang lebih \\
\hline
\end{tabular}

Penulisan angka-angka memperhatikan ketentuan sebagai berikut. Untuk naskah yang ditulis dalam Bahasa Indonesia, angka ribuan diberi penanda titik, misalnya: 1200300 ditulis 1.200.300. Angka yang berupa bilangan desimal ditulis menggunakan tanda koma sampai dua angka di belakang koma, contoh 12,34. Apabila angka bernilai kurang dari 1, maka angka nol di depan koma harus ditulis, contoh 0,12. 
Untuk naskah yang ditulis dalam Bahasa Inggris, angka ribuan diberi tanda koma, misalnya 1200300 ditulis 1,200,300. Angka yang berupa bilangan desimal ditulis menggunakan tanda titik sampai dua angka di belakang koma, contoh 12.34. Apabila angka bernilai kurang dari 1, maka angka nol di depan titik tidak ditulis, contoh.12.

Simbol atau notasi matematika yang berupa huruf alfabet ditulis dalam cetak miring, tetapi yang berupa huruf Yunani ditulis tegak menggunakan simbol yang tepat. Tanda sama dengan dituliskan dengan jeda satu ketuk sebelum dan sesudahnya, sebagai contoh (angka dalam bahasa Inggris): $r=.456 ; p=.008$. Untuk hasil statistik yang bergantung pada derajat bebas seperti nilai t, F, atau $Z$, harus diikuti dengan penulisan nilai derajat bebasnya dalam tanda kurung. Contoh: $t(52)=$ 1.234; $F(1,34)=4.567$. Uji statistik sebaiknya disertai pengitungan effect size: uji-t menggunakan cohen's $d$ dan uji-F menggunakan partial eta squared atau lainnya sesuai referensi yang digunakan.

Hasil penelitian pendekatan kualitatif yang bersumber dari wawancara, pengamatan, penafsiran isi teks, dan lain-lain dikondensasikan, disarikan, atau dibuat ke dalam ringkasan substansial. Jadi, yang disajikan adalah temuan-temuan substansial yang dapat disajikan dalam bentuk tabel-tabel deskriptif untuk memudahkan pemahaman oleh pembaca. Potongan wawancara, deskripsi hasil pengamatan, kutipan teks, dan lain-lain yang memuat temuan-temuan utama atau jawaban dari pertanyaan penelitian disajikan dalam pembahasan sebagai contoh otentik.

\section{Pembahasan}

Berdasarkan hasil evaluasi pada siklus 1 dan 2 yang telah dilakukan tindakan oleh peneliti, diketahui ada peningkatan kemampuan siswa kelas 6 SD dalam menyelesaikan bidang koordinat dengan menggunakan papan berpaku titik. Perbandingan hasil belajar pada akhir siklus 1 dan siklus 2 dideskripsikan pada tabel di bawah ini : 
Tabel 4. Hasil Keseluruhan Nilai Hasil Belajar

\begin{tabular}{|c|c|c|c|}
\hline \multirow[b]{2}{*}{ No } & \multirow[b]{2}{*}{ Indikator Pencapaian Kompetensi } & \multicolumn{2}{|c|}{ Ketercapaian } \\
\hline & & $\begin{array}{c}\text { Rata- } \\
\text { rata }\end{array}$ & KKM \\
\hline 1 & pada papan berpaku & 37,59 & $13,64 \%$ \\
\hline 2 & Tenunjukkan letak benda pada papan berpaku & 38,18 &, $73 \%$ \\
\hline 3 & Menggambar letak benda pada papan berpaku & 47,27 & $27,27 \%$ \\
\hline 4 & $\begin{array}{l}\text { Menentukan letak kordinat posisi benda pada } \\
\text { papan berpaku }\end{array}$ & 54,45 & $31,82 \%$ \\
\hline 5 & $\begin{array}{l}\text { Menentukan letak kordinat posisi tempat pada } \\
\text { papan berpaku }\end{array}$ & 60,13 & $36,36 \%$ \\
\hline 6 & $\begin{array}{l}\text { arkan letak kordinat posisi benda pada } \\
\text { aku }\end{array}$ & 54,45 & $45,45 \%$ \\
\hline 7 & tak titik pada sistem koordinat & 57,72 & $54,55 \%$ \\
\hline 8 & $\begin{array}{l}\text { Menggambar bangun datar pada bidang } \\
\text { koordinat }\end{array}$ & 60,45 & $50,09 \%$ \\
\hline 9 & $\begin{array}{l}\text { Menentukankan letak titik sudut bangun datar } \\
\text { segitiga pada papan }\end{array}$ & 62,90 & $63,64 \%$ \\
\hline 10 & $\begin{array}{l}\text { Menentukan letak titik sudut bangun datar } \\
\text { layang-layang }\end{array}$ & 68,18 & $68,18 \%$ \\
\hline 11 & $\begin{array}{l}\text { Menentukan hasil pencerminan pada bangun } \\
\text { datar segitiga }\end{array}$ & 66,72 & $72,73 \%$ \\
\hline 12 & $\begin{array}{l}\text { Menentukan pencerminan pada bangun datar } \\
\text { layang-layang }\end{array}$ & 75,45 & $81,82 \%$ \\
\hline
\end{tabular}

Berdasarkan hasil nilai ketercapaian tersebut jelas terlihat bahwa semua indikator telah mengalami peningkatan dengan baik. Peningkatan yang terjadi adalah sebagai berikut:

a. Rata-rata kelas pada siklus I Pertemuan pertama yaitu indikator membaca denah sederhana pada papan berpaku mencapai 37,59, sedangkan rata-rata kelas pada siklus II Pertemuan ke-enam yaitu indikator menentukan hasil pencerminan pada bangun datar layang-layang mencapai 75,45. Artinya dengan penerapan papan berpaku terjadi peningkatan sebesar 37,86. 
b. Jumlah siswa yang tuntas KKM pada siklus I Pertemuan pertama yaitu indikator membaca denah sederhana pada papan berpaku mencapai $13,64 \%$ dan jumlah siswa yang tuntas KKM pada siklus II Pertemuan ke-enam yaitu indikator menentukan hasil pencerminan pada bangun datar layang-layang mencapai $81,82 \%$. Artinya dengan penerapan papan berpaku terjadi peningkatan sebesar $68,18 \%$.

Selanjutnya Jika dilihat dari ketercapaian hasil observasi pada aktivitas guru saat melakukan penelitian ini, maka diperoleh hasil sebagai berikut:

Tabel 5. Hasil Keseluruhan Observasi Aktivitas Guru

\begin{tabular}{|c|c|c|c|}
\hline \multirow[b]{2}{*}{ No } & \multirow[b]{2}{*}{ Indikator Pencapaian Kompetensi } & \multicolumn{2}{|c|}{ Ketercapaian } \\
\hline & & Jumlah & $\begin{array}{c}\text { Rata- } \\
\text { rata }\end{array}$ \\
\hline 1 & Membaca denah sederhana pada papan berpaku & 22 & 45,83 \\
\hline 2 & Menunjukkan letak benda pada papan berpaku & 24 & 50,00 \\
\hline 3 & Menggambar letak benda pada papan berpaku & 26 & 54,17 \\
\hline 4 & $\begin{array}{l}\text { Menentukan letak kordinat posisi benda pada } \\
\text { papan berpaku }\end{array}$ & 27 & 56,25 \\
\hline 5 & $\begin{array}{l}\text { Menentukan letak kordinat posisi tempat pada } \\
\text { papan berpaku }\end{array}$ & 29 & 60,42 \\
\hline 6 & $\begin{array}{l}\text { Menggambarkan letak kordinat posisi benda pada } \\
\text { papan berpaku }\end{array}$ & 31 & 64,58 \\
\hline 7 & Menentukan letak titik pada sistem koordinat & 34 & 70,43 \\
\hline 8 & $\begin{array}{l}\text { Menggambar bangun datar pada bidang } \\
\text { koordinat }\end{array}$ & 36 & 75,00 \\
\hline 9 & $\begin{array}{l}\text { Menentukankan letak titik sudut bangun datar } \\
\text { segitiga pada papan }\end{array}$ & 38 & 79,17 \\
\hline 10 & $\begin{array}{l}\text { Menentukan letak titik sudut bangun datar } \\
\text { layang-layang }\end{array}$ & 41 & 85,41 \\
\hline 11 & $\begin{array}{l}\text { Menentukan hasil pencerminan pada bangun } \\
\text { datar segitiga }\end{array}$ & 42 & 87,50 \\
\hline 12 & $\begin{array}{l}\text { Menentukan pencerminan pada bangun datar } \\
\text { layang-layang }\end{array}$ & 44 & 91,67 \\
\hline
\end{tabular}


Berdasarkan hasil observasi tersebut jelas terlihat bahwa yang menjadi perbandingan adalah hasil yang dicapai pada siklus I pertemuan pertama sampai dengan siklus II pertemuan ke-enam telah mengalami peningkatan dengan baik. Peningkatan yang terjadi adalah sebagai berikut:

1) Pada siklus I Pertemuan pertama yaitu indikator membaca denah sederhana pada papan berpaku mencapai skor 22 , sedangkan pada siklus II Pertemuan ke-enam yaitu indikator menentukan hasil pencerminan pada bangun datar layang-layang mencapai skor 44. Artinya dari segi aktivitas guru dengan penerapan papan berpaku terjadi peningkatan sebesar 22 .

2) Pada siklus I Pertemuan pertama yaitu indikator membaca denah sederhana pada papan berpaku mencapai rata-rata 45,83 dan pada siklus II Pertemuan ke-enam yaitu indikator menentukan hasil pencerminan pada bangun datar layang-layang mencapai rata-rata 91,67. Artinya dengan penerapan papan berpaku terjadi peningkatan rata-rata sebesar 45,84 .

Selanjutnya jika dilihat dari ketercapaian hasil observasi pada aktivitas siswa saat melakukan penelitian ini, maka diperoleh hasil sebagai berikut:

Tabel 6. Hasil Keseluruhan Observasi Aktivitas Siswa

\begin{tabular}{|c|l|c|c|}
\hline \multirow{2}{*}{ No } & \multicolumn{1}{|c|}{ Indikator Pencapaian Kompetensi } & \multicolumn{2}{|c|}{ Ketercapaian } \\
\cline { 3 - 4 } & \multicolumn{1}{|c|}{ Jumlah } & $\begin{array}{c}\text { Rata- } \\
\text { rata }\end{array}$ \\
\hline $\mathbf{1}$ & Membaca denah sederhana pada papan berpaku & $\mathbf{2 1}$ & $\mathbf{4 3 , 7 5}$ \\
\hline $\mathbf{2}$ & Menunjukkan letak benda pada papan berpaku & $\mathbf{2 3}$ & $\mathbf{4 7 , 9 1}$ \\
\hline $\mathbf{3}$ & Menggambar letak benda pada papan berpaku & $\mathbf{2 6}$ & $\mathbf{5 4 , 1 7}$ \\
\hline $\mathbf{4}$ & $\begin{array}{l}\text { Menentukan letak kordinat posisi benda pada papan } \\
\text { berpaku }\end{array}$ & $\mathbf{2 7}$ & $\mathbf{5 6 , 2 5}$ \\
\hline $\mathbf{5}$ & $\begin{array}{l}\text { Menentukan letak kordinat posisi tempat pada papan } \\
\text { berpaku }\end{array}$ & $\mathbf{2 9}$ & $\mathbf{6 0 , 4 2}$ \\
\hline $\mathbf{6}$ & Menggambarkan letak kordinat posisi benda pada & $\mathbf{3 1}$ & $\mathbf{6 4 , 5 8}$ \\
\hline
\end{tabular}




\begin{tabular}{|c|c|c|c|}
\hline & papan berpaku & & \\
\hline 7 & Menentukan letak titik pada sistem koordinat & 35 & 72,91 \\
\hline 8 & Menggambar bangun datar pada bidang koordinat & 36 & 75,00 \\
\hline 9 & $\begin{array}{l}\text { Menentukankan letak titik sudut bangun datar } \\
\text { segitiga pada papan }\end{array}$ & 38 & 79,17 \\
\hline 10 & $\begin{array}{l}\text { Menentukan letak titik sudut bangun datar layang- } \\
\text { layang }\end{array}$ & 41 & 85,41 \\
\hline 11 & $\begin{array}{l}\text { Menentukan hasil pencerminan pada bangun datar } \\
\text { segitiga }\end{array}$ & 43 & 89,53 \\
\hline 12 & $\begin{array}{l}\text { Menentukan pencerminan pada bangun datar } \\
\text { layang-layang }\end{array}$ & 45 & 93,75 \\
\hline
\end{tabular}

Berdasarkan hasil observasi tersebut jelas terlihat bahwa yang menjadi perbandingan adalah hasil yang dicapai pada siklus I pertemuan pertama sampai dengan siklus II pertemuan ke-enam telah mengalami peningkatan dengan baik. Peningkatan yang terjadi adalah sebagai berikut:

1) Pada siklus I Pertemuan pertama yaitu indikator membaca denah sederhana pada papan berpaku mencapai skor 21 , sedangkan pada siklus II Pertemuan ke-enam yaitu indikator menentukan hasil pencerminan pada bangun datar layang-layang mencapai skor 45. Artinya dari segi aktivitas guru dengan penerapan papan berpaku terjadi peningkatan sebesar 24 .

2) Pada siklus I Pertemuan pertama yaitu indikator membaca denah sederhana pada papan berpaku mencapai rata-rata 43,75 dan pada siklus II Pertemuan ke-enam yaitu indikator menentukan hasil pencerminan pada bangun datar layang-layang mencapai rata-rata 93,75. Artinya dengan penerapan papan berpaku terjadi peningkatan rata-rata sebesar 50,00.

Meningkatnya kemampuan siswa dalam penguasaan materi pelajaran dibuktikan dengan terjadinya perubahan siswa ketika siswa menjawab soal yang diajukan pada siklus 1 dan pada siklus 2. Pada siklus 2 sebagian besar jawaban sudah terarah dan benar bukti lain dapat dilihat pada lampiran 3 berupa rekapitulasi nilai hasil belajar siswa didik. 
Perolehan hasil belajar siswa nampaknya sudah tercapai baik ditunjukkan dengan keterampilan mereka dalam menyelesaikan bidang koordinat pada papan berpaku. Hal ini menunjukkan bahwa penggunaan papan berpaku secara optimal akan meningkatkan partisipasi dan kemampuan siswa secara signifikan.

Perolehan ini menguatkan hasil penelitian yang pernah dilakukan sebelumnya yang diperoleh dari bacaan kepustakaan terutama dalam memperhatikan keunggulan dan kelemahan pembelajaran dengan menggunakan papan berpaku titik kelemahan dalam penggunaan papan berpaku adalah bila siswa hanya mengikuti penjelasan guru maka siswa akan kebingungan dan pembelajaran akan menjadi sangat membosankan.

Jika dibandingkan antara keunggulan dan kelemahan penggunaan papan berpaku maka keunggulannya lebih dapat diandalkan dibandingkan kelemahannya titik pada penelitian ini guru sebagai peneliti merasa bahwa keunggulan harus dipertahankan sehingga peneliti dapat memperoleh temuan-temuan baru melalui PTK dengan menggunakan papan berpaku.

Berdasarkan hasil penelitian ini dapat diperoleh beberapa informasi antara lain:

1) Terkait dengan hasil penelitian dan teori serta memperhatikan pembelajaran dengan menggunakan papan berpaku pada PTK ini dapat dikatakan bahwa keberhasilan tindakan ini diperoleh karena faktor-faktor sebagai berikut:

a) faktor guru dalam menggunakan papan berpaku guru harus benar-benar berlatih dahulu Sehingga dalam penerapannya kepada siswa sudah tidak canggung lagi. Keberhasilan pembelajaran dalam PTK ini dimungkinkan karena usaha guru dalam penggunaan papan peraga sudah dilakukan dengan maksimal, selain itu guru juga sudah berperan sebagai mana mestinya yakni sebagai motivator fasilitator dan organisator.

b) Faktor siswa pembelajaran ini juga berhasil karena respon siswa terhadap pembelajaran sudah sangat baik dan siswa juga 
amat antusias untuk mengetahui hal-hal yang baru rasa ingin tahunya cukup tinggi.

2) Terkait dengan proses yang terjadi selama penelitian dan keterampilan pelajaran siswa kelas VI siswa SD 114340 Pekan Tolan pada mata pelajaran matematika dapat dikatakan bahwa penggunaan papan berpaku secara optimal untuk menyelesaikan bidang koordinat pada peningkatan hasil belajar. Meningkatnya keterampilan siswa dimungkinkan karena guru dan siswa bersedia saling bekerja sama dalam mencapai indikator keberhasilan yang diharapkan. Hal ini juga didukung oleh peran guru dalam mengarahkan siswa dan kreatif dalam menggunakan alat peraga sedangkan siswa memberikan respon yang baik dalam kegiatan pembelajaran. Secara umum dapat dikatakan bahwa penggunaan papan berpaku secara klasikal sudah tuntas dan ratarata kelas juga sudah tercapai.

\section{Penutup}

Berdasarkan bab III dan jawaban untuk rumusan masalah, maka simpulan hasil karya inovasi ini dinyatakan bahwa media Geoboard berbantuan model pembelajaran Jiqsaw dapat membantu siswa kelas VI untuk meningkatkan hasil belajar Matematika .

Hasil belajar siswapada materi Bidang Koordinat tanpa menggunakan media, maka diperoleh siswa nilai rata-rata 52,73 dengan 11 siswa yang mengalami ketuntasan $(50,50 \%)$ dan 11 siswa yang belum tuntas $(50,50 \%)$ dari total jumlah siswa.

Kemudian dilakukan tindakan menggunakan media geoboard, maka diperoleh nilai rata-rata meningkat menjadi 61,82 dengan 16 siswa yang tuntas $(72,73 \%)$ dan 6 siswa yang belum tuntas $(27,27 \%)$. Setelah dilakukan inovasi pembelajaran menggunakan media media geoboard menggunakan model tipe jiqsaw, maka diperoleh nilai rata-rata kelas 
meningkat menjadi 76,36 dengan 19 siswa yang tuntas (86,36\%) dan 3 siswa yang belum tuntas $(13,64 \%)$.

Media geoboard berbantuan model pembelajaran tipe jiqsaw ini dalam penerapannya sangat memerlukan pendampingan dari guru, apabila pendampingan dari guru sangat serius, maka tingkat keberhasilan akan meningkat pemahaman siswa, sebaliknya jika pendampingan dari guru kurang serius dikhawatirkan siswa mendapat informasi yang kurang sesuai dengan tujuan pembelajaran.

\section{Ucapan Terimakasih}

Ucapan terima kasih disampaikan kepada semua Panitia Kesharlindungdikdas Kemdikbud,Bapak Kepala SDN 114340 Pekan Tolan, dan semua pihak yang telah memberikan dukungan atas terlaksananya penelitian ini sehingga penelitian artikel ini dapat diselesaikan dengan baik.

\section{Daftar Referensi}

Arsyad Azhar. (2011). Media Pembelajaran. Jakarta: PT. Raja Grafindo Persada.

Departemen Pendidikan Nasional. (2000). Kamus Besar Bahasa Indonesia. Jakarta: Balai Pustaka. . (2005). Kamus Besar Bahasa Indonesia. Jakarta: Balai Pustaka.

Isjoni.( 2009). Pembelajaran Kooperatif. Yogyakarta: Pustaka Pelajar.

Istarani, (2012).58 Model Pembelajaran Inovatif. Medan: Media Persada.

Munadi,Y. (2013). Media Pembelajaran; Sebuah Pendekatan Baru. Jakarta: Referensi (GP Press Group)

Siswanto, R., Sugiono, S., \& Prasojo, L. (2018). The Development of Management Model Program of Vocational School Teacher Partnership with Business World and Industry Word (DUDI). Jurnal Ilmiah Peuradeun, 6(3), 365-384. doi:10.26811/peuradeun.v6i3.322

Sukiman.(2012). Pengembangan Media Pembelajaran. Yogyakarta: PT. Pustaka Insan Madani. 
Suprijono Agus. (2010). Cooperatif Learning. Yogyakarta: Pustaka Pelajar

Peraturan Menteri Pendidikan Nasional Nomor 22 Tahun 2006 tentang Standar isi. Jakarta : Direktorat Jenderal Manajemen Pendidikan Dasar dan Menengah Departemen Pendidikan Nasional.2008. 